\title{
PENERAPAN PSAK NO. 45 ( REVISI 2011) DALAM RANGKA EVALUASI PENYAJIAN LAPORAN KEUANGAN YANG WAJAR PADA YAYASAN TAMAN TUNAS MAKASSAR
}

\author{
Jafre-V2I1-03
}

\begin{abstract}
The purpose of study was compare compare the financial statements of Taman Tunas Foundation as a non-profit organization and the financial statements of PSAK 45 as a standard financial report based on Ikantan Akuntan Indonesia (IAI). This study uses comparative method and data source obtained through observation, interview and foundation document in the form of financial statement. Based on this study, it can be seen that Taman Tunas Foundation has not fully applied PSAK 45 in its financial report. This is because the Taman Tunas Foundation still uses the financial statements of the business and Taman Tunas Foundation has not made a cash flow statement so that the financial report of Taman Tunas Foundation has not been transparent for the public.
\end{abstract}

\section{Keywords: PSAK 45, Foundation, and Financial Statement}

\section{PENDAHULUAN}

\section{A. Latar Belakang}

Organisasi nirlaba di Indonesia semakin berkembang. Saat ini banyak berdiri organisasi nirlaba seperti lembaga maupun yayasan yang bergerak di bidang pendidikan, kesehatan, sosial, dan keagamaan. Namun seringkali sulit membedakan antara organisasi bisnis dan organisasi nirlaba dikarenakan kegiatannya yang hampir sama. Tidak adanya keterbukaan dan akuntabilitas kepada masyarakat termasuk publikasi pertanggungjawaban laporan keuangannya merupakan salah satu faktor yang membuat masyarakat sulit membedakan kedua organisasi tersebut. 
Pada prinsipnya organisasi nirlaba berbeda dengan organisasi bisnis. Dalam menjalankan kegiatannya, organisasi nirlaba tidak bertujuan untuk mencari keuntungan. Perlu adanya suatu pertanggungjawaban keuangan pada organisasi nirlaba untuk menilai kinerjanya. Akuntabilitas publik merupakan fenomena yang mulai diamati dalam perkembangan organisasi publik dewasa ini. "Akuntansi merupakan bentuk akuntabilitas publik, transparansi, dan prediktabilitas kinerja organisasi. Hal ini merupakan penekanan besar yang ditujukan pada organisasi publik yang menghendaki keterbukaan, transparansi, perlakuan adil, 
ketidakberpihakan (pada golongan), dan prediktabilitas.” Christensen et al (Halim dan Kusufi, 2012: 15).

Ikatan Akuntan Indonesia mengeluarkan Pernyataan Standar Akuntansi Keuangan (PSAK) No. 45 Tentang Pelaporan Keuangan Organisasi Nirlaba. Standar ini bertujuan untuk mengatur pelaporan keuangan organisasi nirlaba tersebut. Dengan adanya standar pelaporan, diharapkan laporan keuangan organisasi nirlaba dapat lebih mudah dipahami, memiliki relevansi, daya banding dan dapat dipertanggungjawabkan. Laporan keuangan organisasi nirlaba menurut PSAK No. 45 meliputi laporan posisi keuangan, laporan aktivitas dan laporan arus kas serta suatu catatan atas laporan keuangan.

Beberapa fenomena yang terjadi sehubungan dengan penerapan laporan keuangan PSAK 45 adalah Panti Sosial Tresna Werdha merupakan organisasi berbadan hukum yang bergerak dalam bidang pelayanan kesejahteraan sosial bagi para Lanjut Usia agar dapat terpenuhi kebutuhan hidup baik jasmani, rohani dan sosial. Laporan keuangan seharusnya baik untuk Panti Sosial, akan tetapi seringkali kali terjadi ketegangan yang di sebabkan oleh pelaporan keuangan ini (Angelia Novrina Meilani Tinungki dan Rudy J. Pusung: 2014).

Beberapa peneliti melakukan penelitian di sebuah yayasan yang mengelola Perguruan Tinggi swasta di Tasikmalaya. Penelitian dilakukan karena banyaknya perguruan tinggi yang berkembang saat ini sehingga menimbulkan kecurigaan apakah penyajian laporan keuangan yayasan telah memenuhi pelaporan menurut PSAK 45 atau belum diterapkan (Wawan Sukmana dan Yesi Gusman: 2008). 
Sebuah masalah terjadi Kantor Sinode GMIM dimana keraguan dan krisis kepercayaan mucul akibat kurangnya transparansi dan akuntabilitas laporan keuangan yang dapat mempengaruhi tingkat pemberian donatur. Tingkat pemberian donatur yang menurun dapat menyulitkan gereja untuk menjalankan kegiatan operasionalnya. Selain itu, kurangnya kepercayaan publik terhadap laporan pengelolaan keuangan GMIM disebabkan karena faktor internal dan eksternal. Faktor internal yang dimaksudkan adalah masih kurangnya tingkat kesesuaian penyajian laporan keuangan yang dikeluarkan GMIM dibandingkan dengan standar laporan keuangan organisasi nirlaba yang dikeluarkan oleh pemerintah yakni PSAK No. 45 tentang laporan keuangan organisasi nirlaba. Sedangkan faktor eksternal yang dimaksudkan adalah masih kurangnya pemahaman masyarakat terhadap sistem penyajian laporan keuangan yang diterbitkan (Ignasius Rian Gultom: 2015)

Dengan melihat permasalahan di atas, maka kualitas laporan keuangan yang terdiri atas relevan, andal, dapat dibandingkan dan dapat dipahami, akan terwujud melalui terciptanya penerapan PSAK 45 dan kualitas sumber daya manusia pengelola keuangan yang handal dan dapatbertanggung jawab. Hal ini karena standar akuntansi keuangan yang digunakan dalam penelitian ini adalah PSAK 45, maka peneliti melakukan penelitian pada sebuah yayasan di Makassar yaitu Yayasan Pendidikan Taman Tunas yang menyelenggarakan pendidikan sekolah, baik tingkat Kanak-kanak, Dasar, Menengah maupun Atas.

Salah satu lembaga pendidikan yang berada dalam lingkungan Dinas Pendidikan yaitu yayasan pendidikan. Yayasan pendidikan sebagai salah satu 
organisasi yang digerakkan oleh sekelompok orang dan beroperasi dengan cara menghimpun dana masyarakat melalui pungutan SPP (Sumbangan Pembinaan Pendidikan) atau infak-infak lain memiliki kewajiban untuk melaporkan kegiatannya kepada masyarakat atau pihak yang terkait. Mempertanggungjawabkan dan melaporkan dana yang terhimpun merupakan perwujudan akuntabilitas.

Yayasan Taman Tunas didirikan di Makassar dengan Akte Notaris Nomor 29 tanggal 13 Juni 1959 dan mengelola 14 unit persekolahan, mulai dari TK, SD, SMP, dan SMA yang tersebar di tiga provinsi yaitu Sulawesi Selatan, Sulawesi Tenggara dan Sulawesi Barat. Berdasarkan literatur yang ada hingga saat ini bahwa masih jarang penelitian di organisasi nirlaba. Sehingga peneliti tertarik ingin mengetahui lebih dekat tentang organisasi nirlaba dan cara penyajian laporan keuangannya.

\section{B. Rumusan Masalah}

Berdasarkan latar belakang di atas, maka yang menjadi permasalahan pokok dalam penelitian ini yaitu apakah dengan PSAK No. 45 (Revisi 2011) penyajian laporan keuangan Yayasan Taman Tunas Makassar menunjukkan hal yang wajar.

\section{TINJAUAN PUSTAKA}

\section{A. Landasan Teori}

\section{Pengertian Akuntansi menurut Para Ahli}

Akuntansi menurut AAA (American Accounting Association) adalah proses mengidentifikasi, mengukur dan melaporkan informasi keuangan sehingga 
pengguna informasi tersebut dapat mengambil penilaian dan keputusan (Accounting is the process of identifying, measuring, and communicating economic information to permit information judgment and decision by users of the information).

Akuntansi menurut AICPA (American Institute of Certified Public Accountants) adalah seni dalam mengidentifikasian, merekam, mengklasifikasikan, dan meringkas secara signifikan yang berhubungan dengan uang, transaksi, dan peristiwa yang ada, yang setidaknya bersifat financial dan menafsirkan hasilnya.

Akuntansi menurut APB (Accounting Principle Board) adalah kegiatan jasa yang berfungsi menyediakan informasi kuantitatif terutama yang bersifat keuangan yang kemudian dapat digunakan untuk mengambil keputusan

\section{Pengertian dan Tujuan Laporan Keuangan}

Pada dasarnya laporan keuangan merupakan hasil dari proses akuntansi yang bisa digunakan sebagai alat untuk berkomunikasi antara aktivitas perusahaan dengan pihak-pihak yang berkepentingan dengan aktivitas tersebut (Nanu, 2011:119). Kieso (2011:5) mengungkapkan bahwa laporan keuangan merupakan sarana utama bagi suatu perusahaan untuk mengkomunikasikan informasi keuangannya kepada pihak luar. Laporan ini menyediakan informasi mengenai sejarah perusahaan yang diukur dalam bentuk uang.

\section{Laporan Keuangan Entitas Nirlaba}

Standar akuntansi mengenai pelaporan keuangan organisasi nirlaba dikeluarkan oleh Ikatan Akuntan Indonesia (selanjutnya disebut IAI) sebagai 
Standar Akuntansi Keuangan nomor 45 tentang Pelaporan Keuangan Organisasi Nirlaba. Sedangkan Financial Accounting Standards Board (selanjutnya disebut FASB) mengeluarkan Statement of Financial Accounting Standard (selanjutnya disebut SFAS) nomor 117. Adanya standar mengenai pelaporan keuangan organisasi nirlaba bertujuan untuk mengatur pelaporan keuangan entitas nirlaba. Dengan adanya pedoman pelaporan, diharapkan laporan keuangan entitas nirlaba dapat lebih mudah dipahami, memiliki relevansi, dan memiliki daya banding yang tinggi.

\section{a. Tujuan Laporan Keuangan}

Tujuan utama laporan keuangan adalah menyediakan informasi yang relevan untuk memenuhi kepentingan pemberi sumber daya yang tidak mengharapkan pembayaran kembali, anggota, kreditur, dan pihak lain yang menyediakan sumber daya bagi entitas nirlaba.

Pihak pengguna laporan keuangan memililiki kepentingan bersama dalam rangka menilai :

1) Jasa yang diberikan oleh entitas nirlaba dan kemampuannya untuk terus memberikan jasa tersebut;

2) Cara manajer melaksanakan tanggung jawab dan aspek lain dari kinerjanya

Secara rinci, tujuan laporan keuangan, termasuk catatan atas laporan keuangan adalah untuk menyajikan informasi mengenai ;

a) Jumlah dan sifat aset, liabilitas, dan aset neto entitas nirlaba; 
b) Pengaruh transaksi dan peristiwa lain yang mengubah nilai dan sifat aset neto;

c) Jenis dan jumlah arus masuk dan arus keluar sumber daya dalam satu periode dan hubungan antar keduanya;

d) Cara entitas nirlaba mendapatkan dan membelanjakan kas, memperoleh pinjaman dan melunasi pinjaman, dan faktor lain yang berpengaruh terhadap likuiditasnya;

e) Usaha jasa entitas nirlaba

\section{b. Jenis Laporan Keuangan Nirlaba}

\section{1) Laporan Posisi Keuangan}

a) Tujuan Laporan Posisi Keuangan

Menyediakan informasi mengenai aset, liabilitas, dan aset neto serta informasi mengenai hubungan di antara unsur-unsur tersebut pada waktu tertentu. Informasi dalam laporan posisi keuangan yang digunakan bersama pengungkapan, dan informasi dalam laporan keuangan lain dapat membantu pemberi sumber daya yang tidak mengharapkan pembayaran kembali, anggota, kreditur, dan pihak lain untuk menilai :

i. Kemampuan entitas nirlaba untuk memberikan jasa secara berkelanjutan; dan

ii. Likuiditas, fleksibilitas keuangan, kemampuan untuk memenuhi kewajibannya, dan kebutuhan pendanaan eksternal. 
b) Klasifikasi Aset dan Liabilitas

Laporan posisi keuangan, termasuk catatan atas laporan keuangan, menyediakan informasi yang relevan mengenai likuiditas, fleksibilitas keuangan, dan hubungan antara aset dan liabilitas. Informasi tersebut umumnya disajikan dengan pengumpulan aset dan liabilitas yang memiliki karakteristik serupa dalam suatu kelompok yang relatif homogen. Sebagai contoh, entitas nirlaba biasanya melaporkan masing-masing unsur aset dalam kelompok yang homogen, seperti :

i. Kas dan setara kas;

ii. Piutang pasien, pelajar, anggota dan penerima jasa yang lain;

iii. Persediaan

iv. Sewa, asuransi, dan jasa lain yang dibayar di muka

v. Instrumen keuangan dan investasi jangka panjang

vi. Tanah, gedung, peralatan, serta aset tetap lain yang digunakan untuk menghasilkan barang dan jasa

c) Klasifikasi Aset Neto Terikat atau Tidak Terikat

Laporan posisi keuangan menyajikan jumlah masing-masing kelompok aset neto berdasarkan pada ada atau tidaknya pembatasan oleh pemberi sumber daya yang tidak mengharapkan pembayaran kembali, yaitu : terikat secara permanen, terikat secara temporer, dan tidak terikat.

Informasi mengenai sifat dan jumlah dari pembatasan permanen atau temporer diungkapkan dengan cara menyajikan jumlah tersebut dalam laporan keungan atau dalam catatan atas laporan keuangan. 
Pembatasan permanen terhadap aset, seperti tanah atau karya seni, yang diberikan untuk tujuan tertentu, untuk dirawat dan tidak untuk dijual; atau aset yang diberikan untuk investasi yang mendatangkan pendapatan secara permanen dapat disajikan sebagai unsur terpisah dalam kelompok aset neto yang penggunaannya dibatasi secara permanen atau disajikan dalam catatan atas laporan keuangan. Pembatasan permanen kelompok kedua tersebut berasal dari hibah atau wakaf dan warisan yang menjadi dana abadi.

Pembatasan temporer terhadap sumber daya berupa aktivitas operasi tertentu; investasi untuk jangka waktu tertentu; penggunaan selama periode tertentu dimasa depan atau pemerolehan aset tetap; dapat disajikan sebagai unsur terpisah dalam kelompok aset neto yang penggunaannya dibatasi secara temporer atau disajikan dalam catatan atas laporan keuangan.

Aset neto tidak terikat umumnya meliputi pendapatan dari jasa, penjualan barang, sumbangan, dan dividen atau hasil investasi, dikurangi beban untuk memperoleh pendapatan tersebut. Batasan terhadap penggunaan aset neto tidak terikat dapat berasal dari sifat entitas nirlaba.

\section{2) Laporan Aktivitas}

\section{a) Tujuan Laporan Aktivitas}

Menyediakan informasi mengenai pengaruh transaksi dan peristiwa lain yang mengubah jumlah dan sifat aset neto; hubungan antar transaksi dan peristiwa lain; dan bagaimana penggunaan sumber daya dalam pelaksanaan berbagai program atau jasa. 
Laporan aktivitas mencakup entitas nirlaba secara keseluruhan dan menyajikan perubahan jumlah aset neto selama suatu periode. Perubahan aset neto dalam laporan aktivitas tercermin pada aset neto atau ekuitas dalam posisi keuangan.

b) Perubahan Kelompok Aset Neto

Laporan aktivitas menyajikan jumlah perubahan aset neto terikat permanen, terikat temporer, dan tidak terikat suatu periode.

c) Klasifikasi Pendapatan, Beban, Keuntungan, dan Kerugian

Laporan aktivitas menyajikan pendapatan sebagai penambah aset neto tidak terikat, kecuali jika penggunaannya dibatasi oleh pemberi sumber daya yang tidak mengharapkan pembayaran kembali, dan menyajikan beban sebagai pengurang aset neto tidak terikat.

Sumber daya disajikan sebagai penambah aset neto tidak terikat, terikat permanen, atau terikat temporer, bergantung pada ada tidaknya pembatasan. Dalam hal sumber daya terikat yang pembatasannya tidak berlaku lagi dalam periode yang sama, dapat disajikan sebagai sumber daya tidak terikat sepanjang disajikan secara konsisten dan diungkapkan sebagai kebijakan akuntansi.

d) Informasi Pemberi Jasa

Laporan aktivitas atau catatan atas laporan keuangan menyajikan informasi mengenai beban menurut klasifikasi fungsional, seperti menurut kelompok program jasa utama dan aktivitas pendukung. Program pemberian jasa merupakan aktivitas untuk menyediakan barang dan jasa kepada penerima manfaat, 
pelanggan, atau anggota dalam rangka mencapai tujuan atau misi entitas nirlaba. Aktivitas pendukung meliputi semua aktivitas selain program pemberian jasa.

\section{3) Laporan Arus Kas}

a) Tujuan Laporan Arus Kas

Tujuan utama laporan arus kas adalah Menyajikan informasi mengenai penerimaan dan pengeluaran kas dalam suatu periode.

b) Klasifikasi Penerimaan dan Pengeluaran Kas

Laporan arus kas disajikan sesuai PSAK 2 (Revisi 2009) : Laporan Arus

Kas atau SAK ETAP Bab 7 dengan tambahan berikut ini :

i. Aktivitas pendanaan

1. Penerimaan kas dari pemberi sumber daya yang tidak mengharapkan pembayaran kembali yang penggunaannya dibatasi dalam jangka panjang

2. Penerimaan kas dari pemberi sumber daya dan penghasilan invesetasi yang penggunaannya dibatasi untuk pemerolehan, pembangunan dan pemeliharaan aset tetap, atau peningkatan dana abadi

3. Bunga dan dividen yang dibatasi penggunaannya dalam jangka panjang

ii. Pengungkapan informasi mengenai aktivitas investasi dan pendanaan non kas, misalnya sumbangan berupa bangunan atau aset investasi. 


\section{Yayasan}

Menurut UU No. 16 tahun 2001, pengertian yayasan adalah badan hukum yang kekayaannya terdiri dari kekayaan yang dipisahkan dan diperuntukkan untuk mencapai tujuan tertentu di bidang kemanusiaan, keagamaan, dan sosial. Yayasan dapat melakukan kegiatan usaha agar dapat menunjang pencapaian maksud dan tujuannya dengan cara mendirikan badan usaha dan/atau ikut serta dalam suatu badan usaha.

Menurut Bastian (2010: 406), karakteristik utama organisasi nirlaba seperti yayasan, dapat dibedakan dengan organisasi bisnis. Perbedaanya terletak pada cara organisasi memperoleh sumber daya awal yang dibutuhkan untuk melakukan berbagai aktivitas operasionalnya. Organisasi seperti yayasan, umumnya memperoleh sumber daya awal dari sumbangan para anggota dan penyumbang lainnya yang tidak mengharapkan imbalan apapun dari organisasi tersebut.

Menurut UU No. 16 tahun 2001, yayasan mempunyai organ yang tediri dari pembina, pengurus, dan pengawas. Pembina adalah organ yayasan yang memiliki kewenangan yang tidak diserahkan kepada pengurus dan pengawas, contohnya membuat keputusan tentang anggaran dasar. Pengurus merupakan organ yayasan yang melakukan kepengurusan yayasan dan mampu melakukan perbuatan hukum, sekurang-kurangnya terdiri dari ketua, sekretaris, dan bendahara. Sedangkan pengawas adalah organ yang bertugas melakukan pengawasan serta memberikan nasihat kepada pengurus dalam melakukan kegiatan yayasan. 
Sumber pembiayaan yayasan berasal dari sejumlah kekayaan yang dipisahkan dalam bentuk uang. Selain itu yayasan memperoleh sumbangan atau bantuan yang tidak mengikat, seperti wakaf, hibah, hibah wasiat, dan perolehan lain yang tidak bertentangan dengan anggaran dasar yayasan dan/atau peraturan perundang-undangan yang berlaku.

\section{METODE PENELITIAN}

\section{A. Tempat dan Waktu Penelitian}

Penelitian yang dilakukan oleh peneliti yaitu di Yayasan Taman Tunas Makassar yang beralamatkan di Jalan Kumala, No. 151-153 Makassar. Penelitian ini dilaksanakan pada bulan September sampai bulan November 2017.

\section{B. Jenis dan Sumber Data}

1. Jenis data yang digunakan dalam penelitian adalah:

a. Data Kuantitatif, yaitu data yang berkaitan dengan angka-angka seperti jumlah laba/rugi bersih yayasan pada tahun 2016 .

b. Data Kualitatif, yaitu data yang berhubungan dengan data yang diperoleh berupa informasi yayasan, baik itu secara tertulis maupun tidak tertulis.

2. Sumber data yang digunakan adalah:

a. Data Primer, yaitu data yang secara langsung diperoleh dari yayasan berdasarkan hasil yang diperoleh dari observasi dan wawancara dari bendahara umum. 
b. Data Sekunder, yaitu data yang diperoleh dari dokumen yayasan yang ditulis secara berkala dalam bentuk laporan tertulis, yakni berupa laporan keuangan.

\section{Metode Pengumpulan Data}

Dalam penelitian ini, peneliti menggunakan metode pengumpulan data sebagai berikut:

1. Penelitian Pustaka, dimana peneliti mengumpulkan data melalui pencarian buku di perpustakaan, baik berupa literatur-literatur, dan bahan perkuliahan yang berhubungan dengan masalah pokok yang diteliti.

2. Penelitian Lapangan, yaitu peneliti langsung mengamati objek yang akan diteliti dengan cara sebagai berikut :

a. Wawancara, melalui pengamatan ini peneliti bertanya kepada kepala yayasan dan bendahara umum yang telah menyusun laporan keuangan yayasan.

b. Dokumentasi, peneliti mengumpulkan data-data yang berhubungan dengan laporan keuangan yayasan.

\section{Teknik Analisis Data}

Metode analisis data yang digunakan adalah analisis komparatif, yaitu menurut Sugiyono (2003:11) Penelitian komparatif adalah penelitian yang membandingkan keberadaan satu variabel atau lebih pada dua atau sampel yang berbeda, atau pada waktu yang berbeda. Penelitian komparatif adalah sejenis penelitian deskriptif yang ingin mencari jawaban secara mendasar tentang sebab- 
akibat, dengan menganalisis faktor-faktor penyebab terjadinya ataupun munculnya suatu fenomena tertentu.

Penelitian komparatif merupakan penelitian yang sifatnya membandingkan, yang dilakukan untuk membandingkan persamaan dan perbedaan dua atau lebih sifat-sifat dan fakta-fakta objek yang diteliti berdasarkan suatu kerangka pemikiran tertentu.

Untuk mendapatkan data yang dibutuhkan maka akan dilakukan penelitian di lapangan dengan cara wawancara, dokumentasi, dan data-data lain yang diperlukan.

\section{E. Definisi Operasional}

Implementasi dalam penggunaan PSAK 45 adalah penerapan standar akuntansi keuangan untuk organisasi nirlaba. Dalam penelitian ini, implementasi penerapan PSAK 45 hanya difokuskan pada penyajian laporan keuangan Yayasan Taman Tunas apakah telah sesuai atau tidak dengan PSAK 45.

Penyajian laporan keuangan menurut PSAK 45 berbeda dengan penyajian laporan keuangan lainnya karena penyajian laporan keuangan menurut PSAK 45 dapat lebih mudah dipahami, memiliki relevansi, dan memiliki daya banding yang tinggi dalam laporan Yayasan Taman Tunas yang terdiri dari laporan posisi keuangan, laporan aktivitas, laporan arus kas, dan catatan atas laporan keuangan.

\section{HASIL PENELITIAN DAN PEMBAHASAN}

\section{A. Gambaran Umum Objek Penelitian}

\section{Sejarah Singkat}

Yayasan Taman Tunas didirikan di Makassar dengan Akte Notaris Nomor 29 tanggal 13 Juni 1959 oleh Wakil Notaris Sementara Opie Damus Pietersz dan 
telah beberapa kali diubah, terakhir diubah dengan Akte Notaris Nomor 15 tanggal 6 Agustus 2002 oleh Notaris Monika Melany, SH dan telah disahkan oleh Menteri Kehakiman dan HAM serta telah tercatat dalam lembaga negara No. 7 tahun 2003; Tambahan Berita Negara RI tanggal 31 Januari 2003.

Pada tahun ajaran 1985/1986, penyelengaraan SMA Frater dikelola oleh Yayasan Taman Tunas dengan menggunakan biaya yang diusahakan oleh yayasan dan bantuan pemerintah. Saat pemisahannya, penyelengaraan atau pengelolaan sekolah bertanggungjawab kepada kantor wilayah Depdikbud Provinsi Sulawesi Selatan. Akhirnya pada tahun 2004, SMA Frater yang berada dibawah naungan Yayasan Taman Tunas ini mendapat akreditasi A hingga sekarang

Yayasan Taman Tunas mengelola 14 unit persekolahan, mulai dari TK, SD, SMP, dan SMA yang tersebar di tiga provinsi yaitu Sulawesi Selatan, Sulawesi Tenggara, dan Sulawesi Barat.

\section{Visi dan Misi}

a. Visi

"Mewujudkan Unit-Unit Karya Pendidikan yang Unggul dan Terpercaya Berlandaskan Paradigma Pendidikan Hamba-Hamba Kristus untuk Mencerdaskan Generasi Muda.”

b. Misi

1) Mewujudkan cara hidup dan cara kerja melalui layanan yang bermutu dan profesional bersumber pada Yesus Hamba Yahwe yang menderita sebagai energi gerak.

2) Menjalankan fungsi manajemen secara akuntabel, kredibel, transparan dan terukur. 
3) Menginspirasi komunitas pendidikan agar mampu memberikan layanan bersumber pada semangat "Ad Omne Opus Bonum Paratus” ( Siap sedia melaksanakan setiap pekerjaan yang baik ).

4) Mengembangkan semangat korps yang komunikatif, reflektif, mengedepankan pendekatan personal dan sapaan yang memberi kelegaan.

5) Membangun jejaring kerjasama kemitraan internal maupun eksternal.

6) Menangkap peluang untuk perubahan.

7) Memberi layanan, pembelaan, dan pemberdayaan bagi orang kecil, lemah, miskin, bodoh dan tersingkir.

\section{B. Hasil Penelitian}

Berikut akan diuraikan tentang proses mendapatkan data laporan keuangan Yayasan Taman Tunas sebagai jawaban atas rumusan masalah. Selama penelitian di yayasan, telah diperoleh data-data atau dokumen berupa data tentang sejarah singkat yayasan, visi dan misi, motto dan data laporan keuangan tahun 2015 dan tahun 2016 dari Yayasan Taman Tunas.

Dalam penelitian tersebut, ditemukan bahwa Yayasan Taman Tunas menyajikan 3 (tiga) jenis laporan keuangan. Laporan keuangan tersebut meliputi Neraca, Laporan Laba Rugi, dan Perhitungan Perubahan Modal. Berdasarkan hasil wawancara dengan Bendahara Yayasan Taman Tunas bahwa dari laporan keuangan yayasan dibuat berdasarkan kebutuhan yayasan. Laporan keuangan masih tergolong sederhana karena laporan keuangan yayasan hanya disusun berdasarkan keperluan untuk pihak pimpinan yayasan dan pihak eksternal. 


\section{Pembahasan}

\section{Laporan Posisi Keuangan}

a. Paragraf 1, PSAK 45 telah diterapkan pada bagian kepala Laporan Posisi Keuangan. Yayasan Taman Tunas merupakan lembaga pendidikan yang berbentuk badan hukum yang bertujuan untuk mewujudkan unit-unit karya pendidikan yang unggul dan terpercaya berlandaskan paradigma pendidikan Hamba-Hamba Kristus untuk mencerdaskan generasi muda.

b. Paragraf 3, PSAK 45 belum diterapkan oleh Yayasan Taman Tunas. Peneliti menemukan bahwa Yayasan Taman Tunas menyajikan 3 (tiga) laporan keuangan yaitu Laporan Perhitungan Rugi-Laba, Laporan Perubahan Modal, dan Neraca. Dalam PSAK 45, entitas nirlaba seperti Yayasan Taman Tunas seharusnya menyebut neraca sebagai laporan laporan posisi keuangan. Sedangkan laporan perhitungan rugi laba disebut sebagai laporan aktivitas. Dalam PSAK 45 masih ada rekapitulasi arus kas, yang biasa disebut laporan arus kas dan catatan atas laporan keuangan. Berdasarkan wawancara dengan pihak bendahara, Yayasan Taman Tunas tidak membuat laporan arus kas dan catatan atas laporan keuangan karena merasa kurang penting dalam membuat laporan rekapitulasi arus kas dan catatan atas laporan keuangan.

c. Pada paragraf 5, Yayasan Taman Tunas belum menerapkan PSAK 45. Hal ini karena berdasarkan data yang diterima peneliti mulia dari tahun 2015 dan 2016, laporan keuangan yang disajikan Yayasan Taman Tunas belum menggunakan istilah-istilah yang terdapat pada PSAK 45, yaitu: pembatasan 
permanen, pembatasan temporer, sumber daya terikat dan sumber daya tidak terikat.

d. Pada paragraf 10, Yayasan Taman Tunas sudah menerapkan PSAK 45. Neraca pada laporan keuangan Yayasan Taman Tunas menyediakan informasi mengenai aset, liabilitas, dan ekuitas yang dimiliki yayasan selama satu periode akuntansi. Pada dasarnya, ketiga rekening tersebut memiliki arti dan maksud yang sama, akan tetapi Yayasan Taman Tunas sebagai entitas nirlaba perlu menyajikannnya berdasarkan ketentuan PSAK 45. Entitas nirlaba seperti yayasan juga seharusnya menggunakan aset neto karena tidak ada unsur kepemilikan saham dalam yayasan.

e. Pada paragraf 11, PSAK 45 belum diterapkan oleh Yayasan Taman Tunas. Hal ini karena Yayasan Taman Tunas menyajikan total aset, kewajiban dan ekuitas, sedangkan pada neraca Yayasan Taman Tunas istilah aset neto belum digunakan. Aset neto dalam neraca Yayasan Taman Tunas disebut dengan ekuitas.

f. Pada paragraf 12, Yayasan Taman Tunas telah menerapkan PSAK 45. Neraca dalam Yayasan Taman Tunas menyajikan unsure aset homogen yakni kas tunai yayasan, piutang yuyasan, rekening bank, dan lain-lain.

g. Pada paragraf 13, Yayasan Taman Tunas belum menerapkan sepenuhnya PSAK 45. Pada neraca Yayasan Taman Tunas aset telah disajikan berdasarkan urutan likuiditas, dimulai dari kas yayasan, rekening bank dan piutang. 
Berdasarkan Laporan Posisi Keuangan versi Yayasan, ditemukan persamaan antara PSAK 45 dan Praktek Yayasan Taman Tunas. Pada bagian aset lancar dan aset tetap tidak ditemukan perbedaan sehingga tidak perlu diubah berdasarkan PSAK 45. Hanya saja, Yayasan Taman Tunas menyebut Aset Lancar sebagai Aktiva Lancar dan Aset Tidak Lancar sebagai Aktiva Tetap, meskipun pada dasarnya keduanya memiliki pengertian dan tujuan yang sama. Kesesuian PSAK 45 dan Praktik Yayasan Taman Tunas dapat dilihat dari sesuaian berdasarkan tanggal jatuh tempo dan golongan kewajiban itu sendiri dimana Laporan Posisi Keuangan versi Yayasan Taman Tunas telah memisahkan Kewajiban Jangka Pendek dan Kewajiban Jangka Panjang. Namun terdapat perbedaan pada nama rekening dimana Yayasan Taman Tunas menggunakan kewajiban sedangkan PSAK 45 menggunakan liabilitas, meskipun arti dan tujuannya sama.

Menurut PSAK 45 dijelaskan bahwa informasi mengenai likuiditas aset atau saat jatuh tempo liabilitas termasuk pembatasan penggunaan aset seharusnya diungkapkan pada catatan atas laporan keuangan. Namun, berdasarkan data yang diperoleh dari pihak yayasan dan wawancara dengan pihak bendahara, hal itu tidak dapat diungkapkan karena yayasan beluim memiliki catatan atas laporan keuangan.

h. Pada paragraf 14, PSAK 45 belum diterapkan oleh pihak Yayasan Taman Tunas. Dalam neraca Yayasan Taman Tunas kelompok aset neto belum disajikan berdasarkan pada ada atau tidaknya pembatasan oleh pemberi sumber daya yang tidak mengharapkan pembayaran kembali, yaitu terikat 
secara permanen, terikat secara temporer dan tidak terikat. Yayasan Taman Tunas menyebut aset neto terikat secara permanen sebagai modal yayasan, aset neto terikat secara temporer disebut dengan dana donasi dan aset neto tidak terikat disebut dengan saldo penambahan/penurunan tahun berjalan.

\section{Laporan Aktivitas}

a. Paragraf 19 pada PSAK 45 belum diterapkan oleh Yayasan Taman Tunas. Laporan aktivitas Yayasan Taman Tunas disebut dengan laporan perhitungan rugi laba. Pada dasarnya, jelas diketahui bahwa yayasan merupakan entitas nirlaba sehingga laba dan rugi tidak dicantumkan pada laporan keuangan PSAK 45. Bila dilihat secara detail, akun-akun yang ada pada Perhitungan Rugi-Laba Yayasan Taman Tunas masih berbeda dengan Laporan Aktivitas PSAK 45. Perbedaannya terdapat pada penggunaan nama laporan, format, dan beberapa jenis item yang dilaporkan. Sehingga dapat dikatakan bahwa hal ini belum sesuai dengna PSAK 45.

b. Paragraf 20 pada PSAK 45 belum diterapkan oleh Yayasan Taman Tunas. Laporan perhitungan rugi laba yayasan telah menyajikan secara keseluruhan kegiatan operasional dan non operasional yang dijalankan oleh yayasan selama satu periode akuntansi. Berdasarkan laporan perhitungan laba rugi juga dapat digambarkan bagaimana penggunaan sumber daya dalam pelaksanaa berbagai program atau jasa di Yayasan Taman Tunas. Namun laporan tersebut belum menyajikan jumlah perubahan aset neto terikat secara permanen, temporer dan tidak terikat. 
c. Paragraf 23 pada PSAK 45 belum diterapkan pada Yayasan Taman Tunas. Menurut PSAK 45 dijelaskan bahwa laporan aktivitas menyajikan pendapatan sebagai penambah aset neto tidak terikat, kecuali jika penggunaanya dibatasi oleh pemberi sumber daya yang tidak mengharapkan pembayaran kembali, dan menyajikan beban sebagai pengurang aset neto tidak terikat. Akan tetapi, dalam prakteknya laporan perhitungan rugi laba telah menyajikan pendapatan sebagai penambah aset dan beban sebagai pengurang aset, namun aset dalam laporan aktivitas tidak digolongkan menurut pembatasan pemberi sumber daya yang tidak mengharapkan kembali seperti aset neto tidak terikat.

d. Berdasarkan paragraf 25 PSAK 45, perlu diketahui bahwa keuntungan dari investasi Yayasan Taman Tunas disajikan sebagai penambah laba operasional, bukan aset neto tidak terikat karena istilah aset neto tidak terikat belum digunakan pada laporan keuangan Yayasan Taman Tunas.

e. Pada bagian pendapatan dan beban berdasarkan paragraf 27 PSAK 45, yayasan sudah menerapkan PSAK 45 karena laporan keuangannya telah menyajikan pendapatan dan beban secara bruto sedangkan pendapatan investasi seperti pendapatan bunga disajikan secara neto.

f. Pada paragraf 29, PSAK belum diterapkan oleh Yayasan Taman Tunas. Hampir sama dengan bagian c diatas, Laporan Aktivitas menurut PSAK 45 menggambarkan beban sebagai pengurang aset neto tidak terikat. Laporan Perubahan Rugi-Laba Yayasan Taman Tunas sudah menyajikan Beban sebagai pengurang aset, namun tidak menggolongkannya menurut aset neto tidak terikat, terikat temporer dan terikat permanen. Beban juga belum sesuai 
dengan PSAK 45 karena belum menyajikan beban menurut kelompok program jasa utama dan aktivitas pendukung, tetapi laporan Perubahan RugiLaba menggabungkannya sehingga sulit membedakan antara kelompok jasa utama dan aktivitas pendukung.

\section{PENUTUP}

\section{A. Kesimpulan}

Berdasarkan hasil penelitian di atas, maka dapat simpulkan bahwa Yayasan Taman Tunas belum menunjukkan hal yang wajar sesuai PSAK 45. Hal ini karena Yayasan Taman Tunas dalam menyajikan laporan keuangan belum sesuai dengan aturan PSAK 45. Laporan keuangan yang dibuat oleh Yayasan Taman Tunas masih bersifat entitas bisnis sehingga laporan keuangan yayasan tidak berbentuk laporan keuangan sesuai PSAK 45. Yayasan Taman Tunas membuat tiga laporan keuangan yaitu Neraca, Laporan Laba Rugi, dan Laporan Perubahan Modal. Sedangkan setelah disesuaikan berdasarkan PSAK 45, maka laporan keuangan yayasan terdiri dari dua laporan keuangan, yaitu Laporan Posisi Keuangan dan Laporan Aktivitas. Meskipun maksud dan tujuannya sama, namun format laporan keuangan yayasan belum sesuai dengan format laporan keuangan berdasarkan PSAK 45. Selain itu, Yayasan Taman Tunas belum membuat laporan arus kas sehingga proses pemasukkan dan pengeluaran kas yayasan masih belum transparan kepada pihak eksternal.

\section{B. Saran}

Berdasarkan kesimpulan dari hasil penelitian ini, maka peneliti mengusulkan beberapa saran yang kiranya dapat menjadi bahan pertimbangan bagi pengurus Yayasan Taman Tunas sehingga sistem penyajian laporan 
keuangan di Yayasan Taman Tunas dapat diterapkan dengan mengikuti ketentuan menurut PSAK 45. Adapun saran peneliti adalah sebagai berikut:

1. Yayasan Taman Tunas sebaiknya menerapkan PSAK 45 dalam menyajikan laporan keuangan yayasan. Hal ini karena dengan diterapkannya PSAK 45 maka laporan keuangan Yayasan Taman Tunas dapat lebih mudah dipahami, memiliki daya banding dan menambah kepercayaan bagi pihak-pihak yang menggunakan laporan seperti pihak internal dan eskternal.

2. Yayasan Taman Tunas sebaiknya memberi pelatihan dan edukasi kepada bendahara Yayasan Taman Tunas agar mampu membuat laporan keuangan dan mengembangkan sistem akuntansi yayasan berdasarkan PSAK 45 sehingga dapat menyajikan laporan keuanganyang lebih akurat dan transparan bagi pengguna laporan keuangan yayasan.

3. Yayasan Taman Tunas sebaiknya membuat Laporan Arus Kas karena laporan ini dapat membantu pihak yayasan melihat langsung aktivitas kas/bank dan informasi mengenai dari mana saja sumber penerimaan kas dan untuk apa saja kas dikeluarkan akan tersaji secara rinci.

4. Yayasan Taman Tunas perlu menyajikan Catatan Atas Laporan Keuangan karena laporan keuangan ini berfungsi untuk mencatat perkiraan-perkiraan yang dinyatakan dalam neraca, laporan aktivitas, dan laporan arus kas.

\section{Daftar Pustaka}

Adisaputro, Gunawan. 2011. Anggaran Bisnis. Analisis, Perencanaan, dan Pengendalian Laba. Edisi Pertama, Cetakan Kedua. Penerbit UPP STIM YKPN. Yogyakarta. 
Bastian, Indra. 2001. Akuntansi Sektor Publik: Suatu Pengantar. Edisi Ketiga. Penerbit Erlangga. Jakarta.

Bastian, Indra. 2007. Akuntansi Yayasan dan Lembaga Publik. Penerbit Erlangga. Jakarta.

Bestari, Teguh Kristanti Laksmi. 2015. Penerapan PSAK NO. 45 pada Laporan Keuangan Yayasan Himmatun Ayat. Surabaya

Dary, Wulan. 2017. Pengertian Akuntansi Menurut para Ahli (Lengkap). http://www.learniseasy.com//. Jakarta.

Diyani, Ade Rizky, Yazid Yud Padmono, 2013. Analisis Penerapan Psak No. 45 Pada Yayasan Masjid Al Falah Surabaya. Jurnal Akuntansi Manajemen, Sekolah Tinggi Ilmu Ekonomi Indonesia (STIESIA). Surabaya.

Gultom, Ignasius Rian. 2015. Analisis Penerapan PSAK No.45 tentang Laporan Keuangan Organisasi Nirlaba dalam Mencapai Transparansi dan Akuntabilitas Kantor Sinode GMIM. Manado.

Hafild, Emmy. 2008. Standar Akuntansi Keuangan Khusus Partai Politik. Jakarta

Halim, Abdul,dan Kusufi, M. S. 2012. Teori, Konsep, dan Aplikasi Akuntansi Sektor Publik. Salemba Empat. Jakarta.

Harahap, Sofyan Syahri. 2012. Teori Akuntansi - Edisi Revisi2011. Cetakan Kedua belas. PT Raja Grafindo Persada. Jakarta.

Hery. 2013. Teori Akuntansi - Suatu Pengantar. Lembaga Penerbit Fakultas Ekonomi Universitas Indonesia. Jakarta.

Ikatan Akuntan Indonesia 2011. Pernyataan Standar Akuntansi Keuangan No. 45 (Revisi 2011)-Pelaporan Keuangan Entitas Nirlaba. Jakarta

Ikatan Akuntan Indonesia. (2010). PSAK 45: Akuntansi Organisasi Nirlaba. Jakarta: Ikatan Akuntan Indonesia.

Kieso, Weygandt and Paul D. Kimmel 2011. Financial Accounting. IFRS Edition. Wiley, United States of America.

Kristinawati, Yunita. 2014. Pelaporan Keuangan Organisasi Nirlaba (Studi Kasus pada Wahana Visi Indonesia Surabaya). Surabaya

Mamesah, Melisa. 2013. Penerapan PSAK No 45 pada GMIM Efrata Setrum Sonder Kaitannya dengan Kualitas Informasi Laporan Keuangan. Manado. 
Nanu, Hasanuh 2011. Akuntansi Dasar Teori dan Praktik. Mitra Wacana Media, Jakarta.

Nazir, Moh. 2005. Metode Penelitian. Ghalia Indonesia. Jakarta.

Nurlaela, Siti. Mutmainah. 2014. Implementasi PSAK No. 45 dalam Pelaporan Keuangan Entitas Nirlaba Berstatus Badan Layanan Umum. Surakarta.

Pontoh, Chenly Ribka S. 2013. Penerapan Laporan Keuangan Organisasi Nirlaba Berdasarkan PSAK NO. 45 pada Gereja BZL. chenlypontoh@yahoo.co.id. Fakultas Ekonomi Jurusan Akuntansi Universitas Sam Ratulangi, Manado.

Pontoh, Winston. 2013. Akuntansi Konsep dan Aplikasi. Halaman Moeka Publishing. Jakarta

Purwanugraha, H.Andre. 2012. Organisasi Nirlaba di Indonesia: Penerapan Akuntansi, Pelaporan, dan Pertanggungjawaban kepada Publik. http://www.kompasiana.com. Yogyakarta.

Restu Aji, Ida Bagus Made Cahya. 2017. Analisis Penerapan PSAK No. 45 tentang Pelaporan Keuangan Organisasi Nirlaba pada Rumah Sakit Berstatus Badan Layanan Umum (Studi Kasus pada Rumah Sakit Umum Daerah Kota Yogyakarta). Skripsi. Yogyakarta.

Rian Gultom, Ignasius. 2011. Analisis Penerapan PSAK No. 45 tentang :Laporan Keuangan Organisasi Nirlaba dalam Mencapai Transparansi dan Akuntabilitas Kantor Sinode GMIM. Universitas Sam Ratulangi. http:// ID-analisis-penerapan-psak-no45-tentang-laporan-keuanganorganisasi-nirlaba-dalam-m.pdf. Tanggal akses 20 Juli 2017.

Simbolon, Bunga Sinta. 2015. Evaluasi Penyusunan Laporan Keuangan Entitas Nirlaba Berdasarkan PSAK 45 (Studi Kasus pada Yayasan Karya Murni Medan). Medan

Sugiyono. 2003. Metode Penelitian Bisnis. Pusat Bahasa Depdiknas. Bandung

Sugiyono. 2012. Memahami Penelitian Kualitatif. Bandung: ALFABETA

Sukmana, Wawan. 2008. Pengaruh Penyajian Laporan Keuangan Berdasarkan PSAK No. 45 tentang Pelaporan Keuangan Organisasi Nirlaba dan Penerapan Total Quality Management terhadap Kinerja Yayasan. Tasikmalaya

Tinungki, Angelia Novrina Meilani. Pusung, Rudy J. 2014. Penerapan Laporan Keuangan Organisasi Nirlaba Berdasarkan PSAK NO 45 pada Panti Sosial Tresna Werdha Hana. Manado 
Utomo, Riyanto. Nur Qomariah, Indah. 2014. Penerapan PSAK No 45 pada Laporan Keuangan Yayasan Penolong Anak Yatim dan Miskin Perguruan Darul Islam di Kota Gresik untuk Mewujudkan Akuntabilitas Keuangan. Gresik

Widiastutik, Niken. Susilawati, R. Anastasia Endang. 2008. Analisis Penerapan PSAK No. 45 dan PMK No. 76/PMK.05/2008 tentang Pelaporan Keuangan Organisasi Nirlaba pada Unit Bisnis Griya Brawijaya Universitas Brawijaya Berstatus Badan Layanan Umum. Malang

Yuliarti, Norita Citra. 2014. Studi Penerapan PSAK 45 Yayasan Panti Asuhan YABAPPENATIM. Jember 
